\title{
Magdalena Sapała Wieloletnie ramy finansowe na lata 2021-2027 i plan na rzecz odbudowy Unii Europejskiej - uwarunkowania negocjacji, przełomowe decyzje i perspektywa zmian ${ }^{1}$
}

The 2021-2027 Multiannual Financial Framework and the Recovery Instrument: negotiation determinants, groundbreaking decisions and prospects for changes

The article reflects on the negotiations on the EU's 2021-2027 Multiannual Financial Framework and the European Union Recovery Instrument. It gives an overview of exceptional circumstances surrounding the negotiations, broad scope of the legislative package negotiated, and complex decision-making process. The paper also examines the final agreement, in particular as regards the size of the new long-term budget, the shift in spending priorities, and changes in the way the EU actions are financed. The author concludes that despite many difficulties on the road to the agreement, some elements of the outcome can be characterised as groundbreaking. She gives some arguments that a departure from path dependency in financing of the EU is possible. However, whether or not the change is permanent, depends on the successful implementation of the decisions made. The Conference on the Future of Europe gives an opportunity to continue the debate on further reform of the EU finances.

\begin{tabular}{r|l}
\hline DOI & https://doi.org/10.31268/StudiaBAS.2021.25 \\
\hline Słowa kluczowe & $\begin{array}{l}\text { wieloletnie ramy finansowe, budżet UE, Instrument Unii Europejskiej } \\
\text { na rzecz Odbudowy, Unia Europejska, środki własne, negocjacje }\end{array}$ \\
\hline Keywords & $\begin{array}{l}\text { Multiannual Financial Framework, EU budget, European Union } \\
\text { Recovery Instrument, European Union, own resources, negotiations }\end{array}$ \\
\hline O autorce & $\begin{array}{l}\text { doktor nauk ekonomicznych, analityk, Biuro Analiz Parlamentu } \\
\text { Europejskiego } \bullet \boldsymbol{M} \text { magdalena@sapala.pl } \\
\text { ORCID 0000-0002-5507-0482 }\end{array}$ \\
\hline
\end{tabular}

\section{Wstęp}

Wieloletnie ramy finansowe (WRF) są dla Unii Europejskiej (UE) nie tylko planem wydatków na kolejne siedem lat, lecz także odzwierciedleniem wizji Unii, jej priorytetów i kierunków rozwoju, które będą realizowane przez ten okres. To kwestie ważkie i uzgadniane w skomplikowanym procesie decyzyjnym i politycznym. Dlatego negocjacje prowadzące do decyzji o kolejnych WRF są zawsze dużym wydarzeniem dla UE, każdorazowo angażującym instytucje unijne i państwa członkowskie przez kilka lat.

Pomimo dużej wagi decyzji co do kształtu WRF dla funkcjonowania Unii, intensywnych przygotowań i debat na temat potrzebnych reform, a także sporego zainteresowania opinii publicznej negocjacjami dominuje przekonanie, że radykalne zmiany systemu finansowego są

1 Magdalena Sapała jest analitykiem w Biurze Analiz Parlamentu Europejskiego (EPRS), wewnętrznym think tanku Parlamentu Europejskiego. Za treść tego opracowania odpowiada wyłącznie autorka, a wyrażone poglądy nie stanowią oficjalnego stanowiska Parlamentu Europejskiego. 
mało prawdopodobne. Badacze budżetu UE i historii jego reformowania często mówią o jego stagnacji i odwołują się do koncepcji path dependency (zależności od ścieżki) dla wyjaśnienia, dlaczego zmiany w systemie finansowania Unii zachodzą bardzo powoli, a scenariusz negocjowania WRF, choć uciążliwy dla jego głównych aktorów i od dawna krytykowany, jest podobny w każdym siedmioletnim cyklu².

Na tym tle niedawno zakończone negocjacje w sprawie WRF na lata 2021-2027 wydają się wyjątkowe. Droga od propozycji Komisji Europejskiej, przedstawionej 2 maja 2018 r., do ostatecznego porozumienia przyjętego 17 grudnia 2020 r. była długa i pełna nieoczekiwanych zwrotów. Wyjątkowe były nie tylko wydarzenia towarzyszące tym pertraktacjom, takie jak brexit i wybuch pandemii COVID-19, lecz także zakres negocjowanego pakietu legislacyjnego. Rezultatem prowadzonych działań jest plan finansowy określany jako bezprecedensowy, obejmujący wieloletnie ramy finansowe i instrument odbudowy UE po pandemii. Przełomowymi nazywa się decyzje co do sposobów finansowania wspólnych działań UE w kolejnych latach.

Zasadniczym celem artykułu jest wykazanie, że pomimo bardzo trudnych okoliczności, jakie towarzyszyły negocjacjom, oraz złożoności zagadnień, o których decydowano, osiągnięte porozumienie jest wyjątkowe i wprowadza istotne zmiany w systemie finansów UE. Aby to stwierdzić, w niniejszym opracowaniu podjęto próbę zaprezentowania tych aspektów procesu i wyniku negocjacji, które wskazują na ich szczególny charakter i dają podstawę do sądzenia, że odejście od status quo w finansach UE jest możliwe. Zastosowane w artykule metody obejmują analizę i syntezę. Nacisk położono na praktyczne aspekty prezentowanego zagadnienia.

\section{Definiowanie nowych priorytetów i przygotowanie propozycji nowych WRF}

Proces przygotowania WRF na okres po 2020 r. rozpoczął się tuż po przystąpieniu do wdrażania WRF 2014-2020 i był związany z zasadniczą dyskusją nad przyszłością Unii Europejskiej. Z jednej strony był to okres naznaczony kryzysem migracyjnym, obawami przed zagrożeniem terrorystycznym, zmianami klimatu i przeciągającym się procesem wystąpienia Zjednoczonego Królestwa Wielkiej Brytanii i Irlandii Północnej z UE, z drugiej strony - czas debaty nad nowymi priorytetami i sposobami reformowania Unii oraz opracowywania propozycji zmian ${ }^{3}$, w tym w sferze unijnych finansów.

Już w 2014 r., w wyniku ustaleń poczynionych w trakcie negocjacji w sprawie WRF 2014-2020 między Parlamentem Europejskim (PE) i Radą UE, powołano międzyinstytucjonalną Grupę Wysokiego Szczebla ds. Zasobów Własnych. Choć dyskusja na temat reformy zasobów własnych UE toczyła się od wielu lat, system nie był zasadniczo zmieniany od 1988 r. Po raz pierwszy instytucje

2 R. Kaiser, H. Prange-Gstöhl, The European Union Budget in Times of Crises, Nomos, Baden-Baden 2021, S. 27-42, https://doi.org/10.5771/9783845298115-1; R. Ackrill, A. Kay, Historical-Institutionalist Perspectives on the Development of the EU Budget System, "Journal of European Public Policy" 2006, t. 13, nr 1, s. 113-133, https://doi.org/10.1080/13501760500380775.

3 Por.: Deklaracja z Bratysławy, Rada Europejska, 16 września 2016 r.; Deklaracja rzymska, Rada Europejska, 25 marca 2017 r. 
UE zdecydowały się na tak kompleksową diagnozę sytuacji i dały mandat do przedstawienia rekomendacji co do przyszłości finansowania UE. W zaprezentowanym dwa lata później raporcie Grupa bardzo krytycznie oceniła istniejący system zasobów własnych oraz rekomendowała głębokie reformy po stronie zarówno dochodów, jak i wydatków4.

Interesującą debatę na temat reformy źródeł finansowania i wydatków UE podjęła także Komisja Europejska (KE). W opublikowanym w 2017 r. dokumencie wskazała na obszary wymagające zmian oraz na scenariusze rozwoju budżetu w zależności od kierunków rozwoju UE ${ }^{5}$. Ponadto ważne wnioski dla przygotowywanego projektu nowych WRF wynikały ze śródokresowego przeglądu WRF 2014-2020 przeprowadzonego w latach 2016-20176.

Od początku bardzo aktywny w dyskusji i ambitny w swoich oczekiwaniach co do reformy finansów UE był PE. Nieusatysfakcjonowany przebiegiem i wynikiem negocjacji WRF 2014-2020, już w marcu 2014 r. przyjął sprawozdanie, w którym zdefiniował główne problemy i priorytety reformy, czym rozpoczął także debatę na temat następnych WRF ${ }^{7}$. W kolejnych latach przy różnych okazjach PE podkreślał, że w WRF na okres po 2020 r. powinny się znaleźć środki zarówno na tzw. tradycyjne polityki UE, czyli spójność i rolnictwo, jak i na nowe, strategiczne priorytety w takich obszarach, jak polityka migracyjna, bezpieczeństwo, ochrona klimatu, badania i innowacje, a także wsparcie osób młodych na rynku pracy. Parlament Europejski domagał się istotnych zmian po stronie dochodów i zwiększenia autonomii finansowej Unii. Oczekiwał reformy, która zmniejszyłaby znaczenie źródła dochodów opartego na dochodzie narodowym brutto (DNB) państw członkowskich i na podatku VAT oraz wprowadziła nowe źródła związane bezpośrednio ze wspólnymi politykami UE, takimi jak wspólny rynek, wspólna unia energetyczna, polityka środowiskowa i klimatyczna ${ }^{8}$. Po uwzględnieniu potrzeb, priorytetów i zobowiązań UE posłowie PE określili, że pułap wydatków WRF na okres po 2020 r. powinien być na poziomie 1,3\% DNB Unii (bez Wielkiej Brytanii) ${ }^{9}$.

Tuż przed ogłoszeniem przez KE propozycji nowych WRF, podczas nieformalnego spotkania 23 lutego 2018 r., liderzy państw członkowskich dyskutowali o priorytetach finansowych na okres po 2020 r. Wśród politycznych obszarów wymagających zwiększonego finansowania

4 European Commission, Future Financing of the EU. Final Report and Recommendations of the High Level Group on Own Resources, 2016, https://ec.europa.eu/info/sites/default/files/about_the_european_commission/ eu_budget/future-financing-hlgor-final-report_2016_en.pdf [dostęp: 8 września 2021 r.].

5 Dokument otwierający debatę na temat przyszłości finansów UE (COM(2017) 358 final) z dnia 28 czerwca $2017 r$

6 Komunikat Komisji do Parlamentu Europejskiego i Rady. Śródokresowy przegląd/rewizja wieloletnich ram finansowych na lata 2014-2020. Budżet UE ukierunkowany na wyniki (COM(2016) 603 final).

7 Sprawozdanie w sprawie negocjacji dotyczących WRF na lata 2014-2020: wnioski i dalsze działania (2014/2005(INI)).

8 Postulat ten PE podnosi od wielu lat. Więcej na ten temat: A. D'Alfonso, Own Resources of the European Union. Reforming the EU's Financing System, European Parliament, 2021.

9 Rezolucja Parlamentu Europejskiego z dnia 14 marca 2018 r. w sprawie następnych WRF: przygotowanie stanowiska Parlamentu dotyczącego WRF na okres po 2020 r. (2017/2052(INI)) (Dz.Urz. UE C 162 z dnia 10 maja 2019 r.); Rezolucja Parlamentu Europejskiego z dnia 14 marca 2018 r. w sprawie reformy systemu zasobów własnych Unii Europejskiej (2017/2053(INI)) (Dz.Urz. UE C 162 z dnia 10 maja 2019 r.). 
wymienili powstrzymanie nielegalnej migracji, obronę i bezpieczeństwo, a także program Erasmus+. Podkreślali także znaczenie polityki spójności, wspólnej polityki rolnej, inwestycji w badania, innowacje i infrastrukturę paneuropejską. Niektóre państwa zgłosiły gotowość zwiększania swoich wpłat do wspólnego budżetu. Była też zgoda co do konieczności podjęcia wszystkich decyzji szybciej, niż to było podczas negocjacji poprzednich WRF ${ }^{10}$.

Można stwierdzić, że w okresie przygotowawczym, poprzedzającym etap negocjacji, dominowało przekonanie, iż reforma finansów UE jest konieczna, a wyzwania i kryzysy, z którymi mierzy się Unia, wzmacniają potrzebę wspólnego finansowania działań.

\section{Szczególne okoliczności towarzyszące negocjacjom WRF 2021-2027}

Pakiet propozycji legislacyjnych związanych z kolejnymi wieloletnimi ramami finansowymi na lata 2021-2027 KE przedstawiła 2 maja 2018 r. ${ }^{11}$, prawie pół roku po terminie przewidzianym w rozporządzeniu o WRF 2014-202012. Rozpoczęły się wówczas oficjalne negocjacje zakończone formalnym przyjęciem pakietu 17 grudnia 2020 r. Pod wieloma względami były to negocjacje wyjątkowe. Jeśli liczyć od złożenia propozycji do osiągnięcia porozumienia politycznego na szczycie państw członkowskich w lipcu 2020 r., to były one o sześć miesięcy dłuższe od negocjacji w sprawie poprzednich ram finansowych. Kulminacyjne spotkanie szefów rządów i głów państw, na którym uzgadniano porozumienie, trwało pięć dni (17-21 lipca 2020 r.) i było jednym z najdłuższych w historii. Także okres formalnych negocjacji między Radą UE i PE był o miesiąc dłuższy niż w przypadku WRF 2014-202013. Szybkiemu osiągnięciu porozumienia nie sprzyjały ani takie wydarzenia, jak brexit czy wybuch pandemii, ani złożoność pakietu legislacyjnego, który był dyskutowany, ani przede wszystkim proces decyzyjny, dający prawo weta każdemu państwu członkowskiemu zasiadającemu przy stole negocjacyjnym.

\section{Wyjście Wielkiej Brytanii z UE}

Jedną z ważnych okoliczności, które miały wpływ na przebieg rozmów o wieloletnim planie finansowym na okres po 2020 r., były przedłużające się negocjacje w sprawie wystąpienia Wielkiej

10 Rada Europejska, Wystapienie Donalda Tuska po nieformalnym spotkaniu 27 szefów państw i rządów (23 lutego 2018 r.), 2018, https://www.consilium.europa.eu/pl/press/press-releases/2018/02/23/remarks-by-president-donald-tusk-following-the-informal-meeting-of-the-27-heads-of-state-or-government-on-23-february-2018/ [dostęp: 8 września 2021 r.].

11 Pełna lista propozycji aktów legislacyjnych przedłożonych przez Komisję Europejską 2 maja 2018 r.: European Commission, Legal Texts and Factsheets on the EU Budget for the Future, https://ec.europa.eu/info/ publications/factsheets-long-term-budget-proposals_en [dostęp: 8 września 2021 r.].

12 Rozporządzenie Rady (UE, Euratom) nr 1311/2013 określające wieloletnie ramy finansowe na lata 2014-2020 (Dz.Urz. UE L 347 z dnia 20 grudnia 2013 r.), art. 25.

13 Okres jest liczony od formalnego rozpoczęcia negocjacji 13 maja 2013 r. (pierwszy trilog) do ogłoszenia porozumienia politycznego 27 czerwca 2013 r. Więcej na temat porównania negocjacji WRF 2014-2020 i 2021 2027 por.: R. Drachenberg, The Role of the European Council in Negotiating the 2021-2027 MFF, European Parliament, 2021. 
Brytanii z UE. Ze względu na niepewność co do terminu i warunków brexitu KE opóźniła o prawie pół roku przedstawienie propozycji pakietu legislacyjnego na lata 2021-2027. Kwestia wypełnienia luki w budżecie (szacowanej na 12-13 mld EUR rocznie), spowodowanej wystąpieniem Wielkiej Brytanii, była wymieniana wśród głównych problemów wymagających rozstrzygnięcia ${ }^{14}$. Ponadto według niektórych komentatorów brak przedstawiciela Wielkiej Brytanii przy stole negocjacyjnym zmienił dotychczasowy układ sił między państwami płatnikami i beneficjentami oraz miał wpływ na dynamikę rozmów. Uważa się nawet, że jednomyślne uzgodnienie planu odbudowy nie byłoby możliwe, gdyby Wielka Brytania nadal była członkiem UE ${ }^{15}$.

\section{Wybory europejskie w maju 2019 r.}

Innym ważnym wydarzeniem, które miało znaczenie dla przebiegu negocjacji w sprawie nowych WRF, były wybory do Parlamentu Europejskiego przeprowadzone w dniach 23-26 maja 2019 r. i następujący po nich okres obsadzania najważniejszych stanowisk w instytucjach UE. Nigdy wcześniej pertraktacje nie odbywały się w roku wyborczym ${ }^{16}$. Obawiano się, że może to znacznie opóźnić prace nad pakietem finansowym, a co za tym idzie - przesunąć w czasie rozpoczęcie wdrażania programów finansowanych z nowych WRF. Mogłoby to mieć istotne skutki dla beneficjentów środków unijnych. Pomimo tego Rada UE i Rada Europejska nie spieszyły się z przechodzeniem do kolejnych etapów negocjacji. Pierwsze spotkanie liderów państw członkowskich w całości poświęcone pracom nad WRF, zakończone brakiem porozumienia, odbyło się dopiero w lutym 2020 r., a więc rok i dziewięć miesięcy po przedstawieniu propozycji przez Komisję Europejską.

O ile po wyborach europejskich nie zmienił się zasadniczo mandat negocjacyjny PE (został potwierdzony w rezolucji z 10 października 2019 r. ${ }^{17}$ ), o tyle KE w nowym składzie i pod przewodnictwem przewodniczącej U. von der Leyen wprowadziła do debaty nowe projekty, które wymagały dodatkowych środków finansowych. Najważniejszymi z nich były Europejski Zielony Ład i przyspieszenie transformacji cyfrowej ${ }^{18}$.

\section{Wybuch pandemii COVID-19}

Wybuch pandemii COVID-19 wczesną wiosną 2020 r. w największym stopniu zmienił nie tylko dynamikę negocjacji, lecz także zawartość negocjowanego pakietu. W związku z tym nieoczeki-

14 F. Zuleeg, M. Pilati, The MFF: Europe's Other Ticking Clock, European Policy Centre, 2019.

15 J. Haas, E. Rubio, P. Schneemelcher, The MFF Proposal: What's New, What's Old, What's Next?, Jacques Delors Institute, 2018; The EU's Recovery Fund is a Benefit of Brexit, "The Economist", 30 maja 2020 r., https://www. economist.com/europe/2020/05/30/the-eus-recovery-fund-is-a-benefit-of-brexit [dostęp: 10 września 2021 r.].

16 E. Rubio, Negotiating the Next Multiannual Financial Framework in an Electoral Year: Which Consequences?, Jacques Delors Institute, 2018.

17 Rezolucja Parlamentu Europejskiego z dnia 10 października 2019 r. w sprawie wieloletnich ram finansowych na lata 2021-2027 i zasobów własnych: czas, by spełnić oczekiwania obywateli (2019/2833(RSP)).

18 U. von der Leyen, A Union that Strives for More. My Agenda for Europe. Political Guidelines for the Next European Commission 2019-2024, Brussels 2019. 
wanym wydarzeniem i w obliczu nowego, bezprecedensowego kryzysu gospodarczego państwa członkowskie zdecydowały się połączyć niedokończone negocjacje w sprawie WRF z propozycją utworzenia specjalnego funduszu na rzecz odbudowy gospodarki UE. W rezultacie 27 maja 2020 r. Komisja Europejska przedłożyła zmieniony projekt rozporządzenia o WRF na lata 20212027 (redukujący o 3\% pierwotne założenia) i propozycję rozporządzenia w sprawie utworzenia Instrumentu Unii Europejskiej na rzecz Odbudowy Next Generation EU (NGEU) oraz związanych z tym zmian w systemie środków własnych.

Od tego momentu poszerzył się znacznie zakres negocjacji po stronie zarówno wydatkowej, jak i dochodowej przyszłych finansów UE. Co więcej, negocjacje te były utrudnione, ponieważ większość spotkań - ze względu na obostrzenia pandemiczne - musiała się odbywać online. W obawie przed dużym opóźnieniem procesu negocjacyjnego oraz w celu zabezpieczenia ciągłości finansowania dla beneficjentów programów UE Parlament Europejski wezwał KE do przygotowania planu awaryjnego na wypadek braku porozumienia w sprawie nowych WRF przed 1 stycznia 2021 r. ${ }^{19}$ Pomysł ten jednak nie spotkał się z poparciem innych instytucji.

Pomimo tych trudnych warunków, niecałe dwa miesiące po ogłoszeniu nowych propozycji, 21 lipca 2020 r. Rada Europejska osiągnęła porozumienie polityczne co do wszystkich elementów pakietu (tabela 1). Otworzyło to drogę do formalnych rozmów z PE, które zakończyły się 10 listopada 2020 r. Jednakże atmosfera niepewności nadal towarzyszyła negocjacjom. Ostatnią przeszkodą na drodze do osiągnięcia porozumienia była groźba zawetowania całego pakietu finansowego przez Węgry i Polskę. Państwa te sprzeciwiały się zapisom rozporządzenia wprowadzającego mechanizm uzależniający wypłatę środków UE od przestrzegania zasad praworządności, włączonego do pakietu już na samym początku negocjacji w 2018 r. Groźba weta opóźniła o kilka tygodni ostateczne porozumienie. Zostało ono zaaprobowane przez PE 16 grudnia 2020 r. i następnego dnia oficjalnie przyjęte przez Radę UE.

W ramach podsumowania należy stwierdzić, że okres negocjacji od maja $2018 \mathrm{r}$. do grudnia 2020 r. obfitował w wyjątkowe wydarzenia. Szczególnie po wybuchu pandemii dyskusje toczyły się w bardzo trudnych okolicznościach społecznych i gospodarczych, pod dużą presją czasu z powodu kończącego się okresu obowiązywania WRF 2014-2020, a także ze względu na pilną potrzebę uruchomienia NGEU. Problemy wiązały się też z kwestiami czysto organizacyjnymi (spotkania w formule online).

\section{Szeroki pakiet legislacyjny i sposób jego negocjowania}

Pakiet propozycji legislacyjnych złożonych przez KE 2 maja 2018 r. zawierał WRF na lata 20212027, reguły międzyinstytucjonalnej współpracy budżetowej (porozumienie międzyinstytucjonalne), decyzje w sprawie reformy systemu środków własnych, a także propozycję utworzenia nowego mechanizmu wiążącego budżet UE z przestrzeganiem praworządności. Oprócz tych głównych propozycji legislacyjnych, które zwykle są przedstawiane przy okazji przygotowy-

19 Rezolucja Parlamentu Europejskiego z dnia 13 maja 2020 r. zawierająca zalecenia dla Komisji w sprawie siatki bezpieczeństwa chroniącej beneficjentów programów UE: ustanowienie planu awaryjnego dotyczącego WRF (2020/2051(INL)) (Dz.Urz. UE C 323 z dnia 11 sierpnia 2021 r.). 
wania nowej strategii budżetowej UE, KE przedłożyła ponad 40 projektów tzw. rozporządzeń sektorowych, które określają sposoby i reguły wydatkowania środków unijnych, uruchamiają nowe fundusze i programy ${ }^{20}$.

Pakiet propozycji legislacyjnych, zmieniony i poszerzony po wybuchu pandemii ${ }^{21}$, był nie tylko największy i najbardziej nowatorski spośród tych, które kiedykolwiek rozważała UE (np. w kwestii źródeł finansowania budżetu i NGEU), lecz także niezwykle skomplikowany pod względem formalnym (tabela 1).

\section{Tabela 1. Elementy wynegocjowanego pakietu legislacyjnego dotyczącego wieloletnich ram finansowych 2021-2027 i Instrumentu na rzecz Odbudowy i Zwiększania Odporności Next Generation EU}

\begin{tabular}{|c|c|c|}
\hline Akt legislacyjny & Opis & Proces decyzyjny \\
\hline $\begin{array}{l}\text { Rozporządzenie Rady (UE, Euratom) } \\
2020 / 2093 \text { z dnia } 17 \text { grudnia } \\
2020 \text { r. określające wieloletnie } \\
\text { ramy finansowe na lata } 2021-2027 \\
\text { (Dz.Urz. UE L } 433 \text { z dnia } 22 \text { grudnia } \\
2020 \text { r.) }\end{array}$ & $\begin{array}{l}\text { Rozporządzenie określa wieloletnie } \\
\text { ramy finansowe na lata 2021-2027, } \\
\text { w tym roczne pułapy środków na } \\
\text { zobowiązania według kategorii } \\
\text { wydatków (działów) oraz roczne } \\
\text { pułapy środków na płatności }\end{array}$ & $\begin{array}{l}\text { Parlament Europejski udziela zgody } \\
\text { (głosowanie większością głosów } \\
\text { członków PE). Rada UE jedno- } \\
\text { myślnie przyjmuje rozporządzenie } \\
\text { (art. } 312 \text { TFUE) }\end{array}$ \\
\hline $\begin{array}{l}\text { Porozumienie międzyinstytucjo- } \\
\text { nalne z dnia } 16 \text { grudnia } 2020 \text { r. } \\
\text { między Parlamentem Europejskim, } \\
\text { Radą Unii Europejskiej i Komisją } \\
\text { Europejską w sprawie dyscypliny } \\
\text { budżetowej, współpracy w kwe- } \\
\text { stiach budżetowych i należytego } \\
\text { zarządzania finansami oraz w spra- } \\
\text { wie nowych zasobów własnych, } \\
\text { w tym również harmonogramu } \\
\text { wprowadzania nowych zasobów } \\
\text { własnych (Dz.Urz. UE L } 433 \text { I z dnia } \\
22 \text { grudnia } 2020 \text { r.) }\end{array}$ & $\begin{array}{l}\text { Porozumienie określa szczegóły } \\
\text { współpracy trzech instytucji we } \\
\text { wdrażaniu WRF i w używaniu instru- } \\
\text { mentów szczególnych, w kwestiach } \\
\text { dotyczących rocznej procedury } \\
\text { budżetowej, zarządzania środkami } \\
\text { finansowymi Unii i ich ochrony }\end{array}$ & $\begin{array}{l}\text { Wspólne przyjęcie przez Parlament, } \\
\text { Radę i Komisję (art. } 295 \text { TFUE) }\end{array}$ \\
\hline $\begin{array}{l}\text { Decyzja Rady (UE, Euratom) } \\
2020 / 2053 \text { z dnia } 14 \text { grudnia } \\
2020 \text { r. w sprawie systemu zasobów } \\
\text { własnych Unii Europejskiej oraz } \\
\text { uchylająca decyzję 2014/335/UE } \\
\text { (Dz.Urz. UE L } 424 \text { z dnia } 15 \text { grudnia } \\
2020 \text { r.)* }\end{array}$ & $\begin{array}{l}\text { Decyzja określa kategorie zasobów } \\
\text { własnych Unii, pułapy i sposoby ich } \\
\text { obliczania, a także zawiera przepisy } \\
\text { umożliwiające branie pożyczek } \\
\text { na sfinansowanie Instrumentu na } \\
\text { rzecz Odbudowy }\end{array}$ & $\begin{array}{l}\text { Po konsultacji z Parlamentem Euro- } \\
\text { pejskim Rada UE podejmuje decy- } \\
\text { zję jednomyślnie. Decyzja wchodzi } \\
\text { w życie po ratyfikacji we wszystkich } \\
\text { państwach członkowskich, zgodnie } \\
\text { z ich wymogami konstytucyjnymi } \\
\text { (art. } 311 \text { TFUE) }\end{array}$ \\
\hline $\begin{array}{l}\text { Rozporządzenie Parlamentu } \\
\text { Europejskiego i Rady (UE, Euratom) } \\
2020 / 2092 \text { z dnia } 16 \text { grudnia } \\
2020 \text { r. w sprawie ogólnego } \\
\text { systemu warunkowości służącego } \\
\text { ochronie budżetu Unii (Dz.Urz. UE } \\
\text { L } 433 \text { I z dnia } 22 \text { grudnia } 2020 \text { r.) }\end{array}$ & $\begin{array}{l}\text { Ustanawia przepisy niezbędne do } \\
\text { ochrony budżetu UE w przypadku } \\
\text { naruszeń zasad państwa prawnego } \\
\text { w państwach członkowskich }\end{array}$ & $\begin{array}{l}\text { Zwykła procedura ustawodawcza, } \\
\text { w której Parlament decyduje na } \\
\text { równi z Radą UE (art. } 294 \text { TFUE) }\end{array}$ \\
\hline
\end{tabular}

20 Pełna lista aktów prawnych powiązanych z negocjacjami w sprawie WRF znajduje się na stronie Obserwatorium Legislacyjnego PE: https://oeil.secure.europarl.europa.eu/oeil/popups/thematicnote. do?id=2064000\&l=en [dostęp: 8 września 2021 r.].

21 European Commission, MFFLegis/ation, https://ec.europa.eu/info/publications/mff-legislation_en [dostęp: 8 września 2021 r.]. 


\begin{tabular}{|c|c|c|}
\hline $\begin{array}{l}\text { Rozporządzenia sektorowe (ponad } \\
40 \text { aktów prawnych) }\end{array}$ & $\begin{array}{l}\text { Ustanawiają fundusze, programy, } \\
\text { instrumenty we wszystkich obsza- } \\
\text { rach polityk europejskich. Określają } \\
\text { szczegółowe zasady programo- } \\
\text { wania, wydatkowania i wdrażania } \\
\text { środków UE, finansowanych w ra- } \\
\text { mach zarówno WRF 2021-2027, jak } \\
\text { i Instrumentu na rzecz Odbudowy }\end{array}$ & $\begin{array}{l}\text { Zwykła procedura ustawo- } \\
\text { dawcza, w której Parlament } \\
\text { decyduje na równi z Radą UE } \\
\text { (art. } 289 \text { i } 294 \text { TFUE); } \\
\text { Rozporządzenia te mogą być } \\
\text { uzgodnione i przyjęte dopiero } \\
\text { po zatwierdzeniu rozporządzenia } \\
\text { o WRF }\end{array}$ \\
\hline $\begin{array}{l}\text { Rozporządzenie Rady (UE) } \\
2020 / 2094 \text { z dnia } 14 \text { grudnia } \\
2020 \text { r. ustanawiające Instrument } \\
\text { Unii Europejskiej na rzecz Odbu- } \\
\text { dowy w celu wsparcia odbudowy } \\
\text { w następstwie kryzysu związanego } \\
\text { z COVID-19 (Dz.Urz. UE L } 433 \text { z dnia } \\
22 \text { grudnia } 2020 \text { r.) }\end{array}$ & $\begin{array}{l}\text { Określa wysokość, sposób finanso- } \\
\text { wania instrumentu, podział między } \\
\text { pożyczki i granty, zasady alokacji; } \\
\text { Szczegółowe zasady wydatkowa- } \\
\text { nia i wdrażania instrumentu są } \\
\text { określone w rozporządzeniach } \\
\text { sektorowych (por. wyżej). }\end{array}$ & $\begin{array}{l}\text { Decyzja Rady UE podejmowana } \\
\text { kwalifikowaną większością głosów. } \\
\text { Parlament Europejski zostaje } \\
\text { poinformowany o podjętej decyzji } \\
\text { (art. } 122 \text { TFUE) }\end{array}$ \\
\hline
\end{tabular}

* Dodatkowe akty o charakterze nieustawodawczym: rozporządzenie Rady (UE, Euratom) 2021/768 z dnia 30 kwietnia 2021 r. określające środki wykonawcze dotyczące systemu zasobów własnych Unii Europejskiej oraz uchylające rozporządzenie (UE, Euratom) nr 608/2014 i rozporządzenie Rady (UE, Euratom) 2021/769 z dnia 30 kwietnia 2021 r. zmieniające rozporządzenie Rady (EWG, Euratom) nr 1553/89 w sprawie ostatecznych jednolitych warunków poboru środków własnych pochodzących z podatku od wartości dodanej.

Źródło: opracowanie własne.

Jak wskazano w tabeli 1, formalne procesy zatwierdzania elementów pakietu toczyły się według różnych procedur decyzyjnych, opartych na zapisach traktatu lizbońskiego i wyznaczających role dla PE, Rady UE i KE. Zgodnie z nimi jednomyślna decyzja państw członkowskich ${ }^{22}$ była potrzebna do przyjęcia dwóch aktów - rozporządzenia WRF $^{23}$ na lata 2021-2027 i decyzji co do środków własnych UE. Ponadto decyzja o zreformowaniu systemu finansowania budżetu UE wymagała ratyfikacji przez wszystkie państwa członkowskie zgodnie z ich krajowymi wymogami. Osobna procedura, w zasadzie nieuwzględniająca PE, dotyczyła przyjęcia NGEU. Warto podkreślić, że żadna z tych traktatowych procedur nie wyznacza roli Radzie Europejskiej, która „nie pełni funkcji ustawodawczych", lecz jedynie „określa ogólne kierunki i priorytety polityczne” Unii (art. 15 traktatu o UE).

Praktyka negocjacji różni się jednak od formalnych zapisów. Zasadnicze decyzje są podejmowane na szczeblu politycznym przez liderów państw członkowskich zgromadzonych na szczycie Rady Europejskiej. Ich uzgodnienia są kluczowe dla przebiegu negocjacji i to oni wyznaczają moment przejścia do ich kolejnych etapów. Co więcej, treść ich uzgodnień, zawarta w konkluzjach ze szczytu, wybiega daleko poza ustalenia pułapów WRF czy ogólnych kierunków reformy finansów Unii. Dokument ten jest traktowany jako wiążący dla prezydencji Rady UE na kolejnych, formalnych etapach negocjacji z Parlamentem Europejskim ${ }^{24}$.

22 Dodatkowo art. 312 traktatu lizbońskiego w tzw. klauzuli pomostowej przewiduje, że Rada Europejska może jednomyślnie przyjąć decyzję upoważniającą Radę do postanowienia większością kwalifikowaną w sprawie rozporządzenia o WRF. Możliwość ta nigdy nie była wykorzystana.

23 Rozporządzenie Rady (UE, Euratom) 2020/2093 z dnia 17 grudnia 2020 r. określające wieloletnie ramy finansowe na lata 2021-2027 (Dz.Urz. UE L 433 z dnia 22 grudnia 2020 r.).

24 To jeden z przejawów wzmacniania wiodącej roli Rady Europejskiej wśród instytucji UE. Stan ten określany jest jako „nowa międzyrządowość” (new intergovernmentalism). J. Barcz, Od lizbońskiej do postlizbońskiej Unii 
W konkluzjach Rady Europejskiej z 21 lipca 2020 r. zawarto wiele szczegółów wykraczających poza rozporządzenie o WRF i decyzję o środkach własnych Unii. Dotyczyły one na przykład reguł podziału i programowania wydatków w ramach polityk spójności i rolnej, które powinny podlegać współdecydowaniu z udziałem PE w procesie negocjowania rozporządzeń sektorowych, a więc w zwykłej procedurze ustawodawczej. PE wielokrotnie wyrażał sprzeciw wobec tak dużego zaangażowania Rady Europejskiej w negocjacje w sprawie WRF. Niemniej kiedy zespół negocjacyjny Parlamentu zasiadł do rozmów z prezydencją niemiecką reprezentującą Radę UE (pierwsze takie spotkanie odbyło się 27 sierpnia 2020 r.), bardzo trudno mu było zmienić kształt pakietu uzgodnionego przez Radę Europejską.

Kluczowa trudność w tych negocjacjach polegała na włączeniu do pakietu i wzajemnym powiązaniu wielu bardzo istotnych propozycji i na konieczności uzyskania de facto jednomyślnej zgody wszystkich państw członkowskich i Parlamentu Europejskiego co do całości ${ }^{25}$. Negocjacje toczyły się według zasady "Nic nie jest uzgodnione dopóty, dopóki wszystko nie jest uzgodnione" (Nothing is agreed until everything is agreed), co oznacza, że elementy pakietu nie mogły być rozdzielone i brak zgody w jednym aspekcie mógł zagrozić całości porozumienia. W rezultacie uzgodnienia budżetowe, takie jak pułapy wydatków na poszczególne lata i programy WRF, mogły zostać zablokowane przez brak porozumienia co do innych kwestii finansowych i politycznych, takich jak zasady podziału Instrumentu na rzecz Odbudowy czy mechanizm uwarunkowania wypłat od przestrzegania praworządności.

Pomimo tak skomplikowanego pakietu propozycji legislacyjnych i wielu słabości sposobu decydowania ${ }^{26}$ ostatecznie decyzję udało się podjąć i zatwierdzić akty prawne konieczne do uruchomienia WRF na lata 2021-2027 jeszcze przed zakończeniem obowiązywania ram na lata 2014-2020. W ten sposób co prawda uchroniono się przed wprowadzeniem prowizorium budżetowego na 2021 r. $^{27}$, ale nie uniknięto opóźnienia procesu wdrażania nowych programów i funduszy.

Europejskiej. Główne kierunki reformy ustrojowej procesu integracji europejskiej, Wolters Kluwer, Warszawa 2020, s. 241-242, 249-251.

25 Warto dodać, że formalne kompetencje Parlamentu Europejskiego w sprawach finansów UE są niesymetryczne - inne w sprawie planowania wieloletnich wydatków (WRF), inne w procedurze budżetu rocznego i jeszcze inne w zakresie ustalania dochodów Unii. Uważa się jednak, że faktyczny wpływ PE na kształtowanie budżetu UE jest tylko w części zdeterminowany przez formalne procedury. Por.: M.W. Bauer, S. Becker, Assessing the European Parliament's Power of the Purse: Rights, Capabilities, and Strategies [w:] The New Politics of the European Union Budget, red. S. Becker, M.W. Bauer, A. De Feo, Nomos, Baden-Baden 2017, s. 173-194.

26 Zarówno instytucje UE, jak i eksperci krytykują sposób podejmowania decyzji o finansach UE. Por.: European Court of Auditors, Future of EU Finances: Reforming How the EU Budget Operates. Briefing Paper, Luxembourg 2018, https://www.eca.europa.eu/other\%20publications/briefing_paper_mff/briefing_paper_mff_en.pdf [dostęp: 10 września 2021 r.]; Rezolucja Parlamentu Europejskiego w sprawie negocjacji dotyczących WRF na lata 2014-2020: wnioski i dalsze działania (2014/2005(INI)) (Dz.Urz. UE C 443 z dnia 22 grudnia 2017 r.); S. Neheider, I. Santos, Reframing the EU Budget-Decision-Making Process, ,Journal of Common Market Studies" 2011, t. 49, nr 3, s. 631-651, https://doi.org/10.1111/j.1468-5965.2010.02148.x.

27 W grudniu 2020 r., na kilka tygodni przed upływem okresu obowiązywania WRF 2014-2020, administracja UE przygotowywała już odpowiednie akty umożliwiające uruchomienie miesięcznego prowizorium budżetowego (provisional twelfth) na wypadek braku nowych WRF i opóźnienia przyjęcia budżetu na 2021 r. 


\section{Przełomowe rezultaty negocjacji}

Ponieważ zakres negocjowanych zagadnień był bardzo duży, oceny uzgodnionego pakietu różnią się w zależności od analizowanego aspektu. Większość komentatorów i analityków zgadza się jednak co do tego, że plan odbudowy dla UE po pandemii, składający się z WRF na lata 2021-2027 i Instrumentu na rzecz Odbudowy na lata 2021-2023, to projekt bez precedensu, osiągnięcie przełomowe dla UE, najważniejszy krok od czasu wprowadzenia wspólnego rynku²8. Za wyjątkowe można uznać m.in. ogólną uzgodnioną kwotę, zawierającą WRF i NGEU, a także wzrost udziału w wydatkach budżetowych takich priorytetów, jak zielona i cyfrowa transformacja oraz nowe źródła i sposoby finansowania tych wydatków.

\section{Wysokość uzgodnionego pakietu finansowego}

Ogólna kwota uzgodnionego planu odbudowy dla UE wynosi prawie 2 bln EUR (wszystkie kwoty podane są w cenach z 2018 r.) i składa się z WRF na lata 2021-2027 (1,074 bln EUR) i NGEU na lata $2021-2023^{29}$ (750 mld EUR). Kwota ta stanowi 1,8\% dochodu narodowego brutto UE (WRF $1,1 \%$ DNB i NGEU - 0,7\% DNB) ${ }^{30}$. Są to największe środki, jakie kiedykolwiek były wydawane w ramach unijnego budżetu ${ }^{31}$.

Ze względu na połączenie WRF z NGEU kwota uzgodnionych siedmioletnich ram finansowych nie była tym razem bardzo eksponowanym aspektem porozumienia ${ }^{32}$. Warto jednak pamiętać, że o ile NGEU jest instrumentem jednorazowym, stworzonym w ściśle określonym celu, ze stosunkowo krótkim horyzontem czasowym, o tyle WRF to podstawowy, traktatowy i długo-

28 Recovery Fund is a Huge Breakthrough for the EU, "The Financial Times", 21 lipca 2020 r.; Why the EU is Becoming More Like a Chekhov Play, "The Economist”, 25 lipca 2020 r., https://www.economist.com/europe/2020/07/23/ why-the-eu-is-becoming-more-like-a-chekhov-play [dostęp: 10 września 2021 r.].

29 Do 31 grudnia 2023 r. mogą być zaciągane zobowiązania prawne, a do 31 grudnia 2026 r. można realizować płatności związane z wydatkami z NGEU. Por.: art. 3 rozporządzenia Rady (UE) 2020/2094 z dnia 14 grudnia 2020 r. ustanawiającego Instrument Unii Europejskiej na rzecz Odbudowy w celu wsparcia odbudowy w następstwie kryzysu związanego z COVID-19 (Dz.Urz. UE L 433 z dnia 22 grudnia 2020 r.).

30 European Commission, Integrated Financial and Accountability Reporting IFAR. Financial Year 2020, 2021, https://ec.europa.eu/info/sites/default/files/about_the_european_commission/eu_budget/overview_ifar_ web1.pdf [dostęp: 10 września 2021 r.], s. 40.

31 Choć WRF i NGEU różnią się sposobem finansowania, wdrażania i okresem obowiązywania, są też ze sobą połączone. Na przykład środki na spłatę odsetek od pożyczek zaciągniętych w ramach NGEU (12,9 mld EUR) są częścią WRF, a ok. 10\% środków z NGEU będzie zasilać wybrane programy w ramach WRF (np. 10,9 mld EUR trafi do Funduszu Sprawiedliwej Transformacji). Ponadto bezzwrotne subsydia z NGEU będą zapisywane w budżetach rocznych jako zewnętrzne dochody przeznaczone na określony cel (external assigned revenue). Por. M. Sapała, N. Thomassen, Recovery Plan for Europe: State of Play, European Parliament, 2021.

32 Z analizy aktywności liderów państw członkowskich na Twitterze wynika, że nawet premierzy państw z tzw. grupy skąpców (frugal group), którzy zwykle bardzo podkreślają konieczność cięć w WRF, tym razem wcale nie wspominali o tej kwestii. Por. R. Drachenberg, op. cit., s. 10. 
okresowy sposób finansowania wszystkich polityk i działań UE. Wysokość WRF jest niezwykle istotna dla funkcjonowania $U E^{33}$.

Uzgodniona kwota WRF na lata 2021-2027 jest zbliżona do tej z lat 2014-2020, i to pomimo zmniejszenia liczby państw członkowskich ${ }^{34}$. Co więcej, dzięki staraniom PE pułap ten będzie corocznie podnoszony, aby w 2027 r. osiągnąć wysokość 1085,3 mld EUR (tj. o 1,3\% mniej niż w propozycji KE z maja 2020 r. i o 18\% mniej, niż oczekiwał Parlament w swoim stanowisku negocjacyjnym) $)^{35}$. Te dodatkowe środki (11 mld EUR) będą pochodzić z kar nakładanych w ramach polityki konkurencji UE, zgodnie z nowym mechanizmem wprowadzonym w art. 5 rozporządzenia o WRF 2021-2027, i wesprą programy flagowe UE, takie jak Horyzont Europa, Erasmus+, Kreatywna Europa oraz Prawa i Wartości ${ }^{36}$. Mechanizm ten i możliwość podniesienia pułapów ram finansowych dla sfinansowania wybranych programów są rozwiązaniami przełomowymi, nigdy dotąd niestosowanymi w budżecie UE.

\section{Nowe priorytety budżetowe}

W nowych wieloletnich ramach finansowych udział wydatków na tzw. nowe priorytety ${ }^{37}$ wzrośnie do 29,9\% (z 22,8\% w WRF 2014-2020) i zbliży się do tych przeznaczonych na wspólną politykę rolną i morską (31,9\%) oraz na politykę spójności $(30,7 \%)$ (tabela 2). Przy ogólnej kwocie WRF 2021-2027 zbliżonej do kwoty z poprzedniego okresu programowania takie zmiany są wynikiem cięć środków na tzw. tradycyjne polityki - rolną (spadek o 4,1 p.p.) oraz spójności (o 3,3 p.p.) - i jednoczesnego zwiększenia środków na zadania związane z wyzwaniami, które nabrały wagi w ostatniej dekadzie ${ }^{38}$. Jak wynika z danych zamieszczonych w tabeli 2 , wzrasta

33 Rezolucja Parlamentu Europejskiego w sprawie konkluzji z nadzwyczajnego posiedzenia Rady Europejskiej w dniach 17-21 lipca 2020 r. (2020/2732(RSP)). W podobnym duchu broniła WRF także Francja: France Says EU Recovery Fund Cannot Come at Expense of Long-Term Budget, Reuters, 26 maja 2020 r., https://www.reuters. com/article/us-eu-recovery-france-idINKBN2321NP [dostęp: 8 września 2021 r.].

34 Porównanie w cenach z 2018 r., oparte na kwotach uwzględniających wystąpienie Wielkiej Brytanii z UE i włączenie do budżetu Europejskiego Funduszu Rozwoju. Por.: Zalecenie w sprawie projektu rozporządzenia Rady określającego wieloletnie ramy finansowe na lata 2021-2027 (2018/0116(APP)), s. 35. Więcej o porównywaniu WRF z różnych okresów por.: M. Parry, M. Sapała, 2021-2027 Multiannual Financial Framework and New Own Resources. Analysis of the Commission's Proposal, European Parliament, 2018, s. 2-3.

35 European Parliamentary Research Service, Visualising the European Union 2021-2027 MFF and Recovery Instrument, https://www.europarl.europa.eu/thinktank/infographics/mff2021-2027/index.html [dostęp: 8 sierpnia 2021 r.].

36 W sumie w wyniku negocjacji z Radą UE Parlament uzyskał 15 mld EUR na wzmocnienie programów flagowych powyżej kwot określonych przez Radę Europejską na szczycie w lipcu 2020 r. oraz dodatkowy 1 mld EUR na instrumenty elastyczności. M. Sapała, M. Pari, N. Kresnichka-Nikolchova, EU Financing for 2021-2027, European Parliament, 2020.

37 W tym wydatki w ramach działów: 1, 2b, 4, 5, 6 oraz na działania na rzecz środowiska i klimatu (por. tabela 2).

38 M. Sapała, Cohesion, Resilience and Values. Heading 2 of the 2021-2027 MFF, European Parliament, 2021; K. Kowald, Natural Resources and Environment. Heading 3 of the 2021-2027 MFF, European Parliament, 2021. 
Tabela 2. Procentowy udział poszczególnych działów w WRF 2014-2020 i 2021-2027*

\begin{tabular}{|l|c|c|}
\hline \multicolumn{1}{|c|}{ Działy WRF 2021-2027 } & WRF 2014-2020 (w \%) & WRF 2021-2027 (w \%) \\
\hline 1. Jednolity rynek, innowacje i gospodarka cyfrowa & 10,8 & 12,4 \\
\hline 2. Spójność, odporność i wartości & 35,8 & 35,2 \\
\hline 2a. Spójność gospodarcza, społeczna i terytorialna & 34,0 & 30,7 \\
\hline 2b. Odporność i wartości & 1,8 & 4,4 \\
\hline 3. Zasoby naturalne i środowisko, w tym: & 36,9 & 33,2 \\
\hline - polityka rolna i morska & 36,0 & 31,9 \\
\hline - działania na rzecz środowiska i klimatu & 0,3 & 1,2 \\
\hline 4. Migracja i zarządzanie granicami & 0,9 & 2,1 \\
\hline 5. Bezpieczeństwo i obrona & 0,2 & 1,2 \\
\hline 6. Sąsiedztwo i świat & 8,8 & 9,1 \\
\hline 7. Europejska administracja publiczna, w tym: & 6,5 & 6,8 \\
\hline wydatki administracyjne instytucji & 5,2 & 5,2 \\
\hline
\end{tabular}

* Procenty częściowe w działach nie sumują się ze względu na zaokrąglenia i marginesy na nieprzewidziane wydatki.

Źródło: opracowanie własne na podstawie rezolucji Parlamentu Europejskiego z dnia 14 listopada 2018 r. w sprawie wieloletnich ram finansowych na lata 2021-2027 (2018/0166R(APP)) oraz rozporządzenia Rady (UE, Euratom) 2020/2093 z dnia 17 grudnia 2020 r. określającego wieloletnie ramy finansowe na lata 2021-2027 (2020/2093).

udział wydatków w działach: 1 - Jednolity rynek, innowacje i gospodarka cyfrowa, 4 - Migracja i zarządzanie granicami, 5 - Bezpieczeństwo i obrona, 6 - Sąsiedztwo i świat oraz na działania na rzecz środowiska i klimatu. Są to obszary utożsamiane z tzw. europejskimi dobrami publicznymi i traktowane jako europejska wartość dodana ${ }^{39}$.

Przejawem wzrostu znaczenia nakładów na wspomniane dziedziny są także zmiany w strukturze WRF. Po raz pierwszy wydzielono specjalne działy dla wydatków na politykę migracyjną i zarządzanie granicami (dział 4) oraz na bezpieczeństwo i obronę (dział 5). Ponadto zarówno w NGEU, jak i w nowym wieloletnim budżecie większą wagę niż wcześniej przywiązuje się do włączania celów horyzontalnych związanych z nowymi wyzwaniami, przed którymi stoi UE, do planowanych wydatków, a także do wyznaczania minimalnych udziałów tych wydatków w budżecie (mainstreaming). W przypadku środków przeznaczonych na działania w dziedzinie klimatu ich wysokość ma wynieść 30\% funduszy z WRF i NGEU (o 10\% więcej niż w WRF 2014-2020 i o 5\% więcej, niż zaproponowała Komisja Europejska). Ustalono także roczną minimalną wysokość kosztów działań związanych z bioróżnorodnością - 7,5\% od 2024 r. i 10\% od 2026 r. - które mają być pokryte z funduszy WRF. W rezultacie przewiduje się, że wydatki na wspomniane cele istotnie wzrosną w porównaniu z latami 2014-2020 i będą najwyższe w historii UE ${ }^{40}$.

39 F. Clemens, J. Pisani-Ferry, A Primer on Developing European Public Goods, „EconPol Policy Report” 2019, nr 16.

40 A. D'Alfonso, Matching Priorities and Resources in the EU Budget. Climate Action, Migration and Borders, European Parliament, 2021. 


\section{Nowe zasoby własne UE}

Przełomowa decyzja państw członkowskich o utworzeniu instrumentu odbudowy finansowanego z pożyczek wziętych na rynkach finansowych przyspieszyła prace nad nowymi dochodami dla Unii. Bez konkretnych zmian w tej dziedzinie spłata pożyczek przeznaczonych na sfinansowanie NGEU wymagałaby wzrostu krajowych składek do budżetu albo znacznych cięć w wydatkach WRF po 2027 r.

W zatwierdzonym pakiecie legislacyjnym znalazły się zapisy wyznaczające konkretne etapy wprowadzania nowych zasobów własnych budżetu UE. Zabiegał o nie szczególnie PE ${ }^{41}$. Już od 2021 r. budżet będzie finansowany z wkładu obliczonego na podstawie wagi niepoddawanych recyklingowi odpadów opakowaniowych z tworzyw sztucznych (tzw. podatek od plastiku). Jest to pierwsze od końca lat 80. nowe źródło dochodów własnych Unii. Uzgodniono też, że nowe zasoby wprowadzone po 2021 r. mają być wystarczające do spłaty kwoty głównej i należnych odsetek w ramach NGEU (spłata nie powinna skutkować nieuzasadnionym zmniejszaniem wydatków w ramach WRF) ${ }^{42}$.

Instytucje UE zobowiązały się do działania na rzecz realizacji trzyetapowego harmonogramu, zgodnie z którym do końca 2026 r. KE ma przedłożyć propozycje nowych źródeł dochodów własnych, a Rada UE ma przeprowadzić nad nimi dyskusje. Zgodnie z planem najszybciej w koszyku nowych zasobów własnych mają się znaleźć wkłady oparte na „mechanizmie dostosowania cen na granicach z uwzględnieniem emisji $\mathrm{CO}_{2}$ ", na opłacie cyfrowej oraz na unijnym systemie handlu uprawnieniami do emisji (ETS). W ostatnim etapie KE ma zaproponować jeszcze inne źródła dochodów własnych, np. podatek od transakcji finansowych czy wkład związany z nową wspólną podstawą opodatkowania osób prawnych.

Gdy weźmie się pod uwagę dotychczasową niechęć do zmian w zakresie źródeł finansowania ze strony państw członkowskich, plan zapisany w porozumieniu wydaje się bardzo ambitny. Jego realizacja wymaga nie tylko intensywnych prac legislacyjnych i działań politycznych na szczeblu UE, lecz także akceptacji na szczeblu państw członkowskich, które będą te zmiany ratyfikować. Niemniej od bardzo dawna Unia nie była tak bliska wprowadzenia tak istotnych zmian do systemu zasobów własnych.

\section{Podsumowanie}

Negocjacje w sprawie wieloletnich ram finansowych nigdy nie były łatwe ani krótkie ${ }^{43}$. Nie inaczej było z porozumieniem co do WRF 2021-2027. Chociaż dyskusje nad pożądanymi refor-

41 A. Vitrey, How and Why Did the European Parliament Influence the Reform of the Own Resources System? [w:] EU Financing for Next Decade. Beyond the MFF 2021-2027 and the Next Generation EU, red. B. Laffan, A. De Feo, European University Institute, Florence 2020.

42 Porozumienie międzyinstytucjonalne z dnia 16 grudnia 2020 r. między Parlamentem Europejskim, Radą Unii Europejskiej i Komisją Europejską w sprawie dyscypliny budżetowej, współpracy w kwestiach budżetowych i należytego zarządzania finansami oraz w sprawie nowych zasobów własnych, w tym również harmonogramu wprowadzania nowych zasobów własnych (Dz.Urz. UE L 433 I z dnia 22 grudnia 2020 r.).

43 Dotychczas najkrócej, 16 miesięcy, trwały negocjacje w sprawie pierwszej wieloletniej perspektywy finansowej na lata 1988-1992. Por.: E. Rubio, op. cit. 
mami systemu finansowania UE rozpoczęły się na długo przed przedstawieniem w maju 2018 r. propozycji pakietu legislacyjnego przez Komisję Europejską, PE był gotowy do negocjacji już w listopadzie 2018 r., a przez kolejne prezydencje Rady UE były prezentowane kompromisowe rozwiązania, to i tak kluczowe decyzje na szczeblu liderów państw członkowskich podjęto niemalże w ostatniej chwili. Osiągnięciu porozumienia nie sprzyjały tak wyjątkowe wydarzenia, jak brexit czy wybuch pandemii, ale przede wszystkim zasada jednomyślności stosowana de facto wobec całego tak skomplikowanego pakietu legislacyjnego.

Pomimo tych trudnych okoliczności udało się osiągnąć porozumienie, w wyniku którego przez najbliższe lata UE będzie dysponowała największymi środkami finansowymi w swojej historii. W większym stopniu niż dotychczas z budżetu unijnego będą finansowane zadania związane z nowymi istotnymi problemami w sferze ochrony klimatu, gospodarki cyfrowej i innowacji, polityki migracyjnej i bezpieczeństwa. Ponadto po raz pierwszy od ponad 30 lat lista źródeł dochodów własnych Unii poszerza się o nowe pozycje, a historyczna decyzja o utworzeniu NGEU przełamała temat tabu, jakim były sposoby finansowania wspólnych działań. Niewątpliwie są to zmiany, które można nazwać przełomowymi, i sygnały, że wyjście ze stanu stagnacji oraz zależności od ścieżki w kształtowaniu finansów UE jest możliwe. Niemniej jednak to, czy będą one miały trwałe konsekwencje dla kształtu budżetu UE, zależy w dużej mierze od sposobu i oceny ich wdrażania. Ewentualny sukces instrumentu odbudowy przesądzi zaś o tym, czy państwa członkowskie będą skłonne podejmować podobne ryzyko finansowe w sytuacjach innych niż kryzys spowodowany pandemią.

Unia rozpoczęła już wdrażanie WRF 2021-2027 i NGEU, a także przygotowania legislacyjne do wprowadzenia kolejnych źródeł własnych. Jest to zadanie pod wieloma względami niełatwe. Jeśli weźmie się pod uwagę wielkość planowanego budżetu i ambitne cele, jakie te środki finansowe mają pomóc osiągnąć, ich sprawna absorpcja, zgodna z unijnymi regułami i prowadząca do oczekiwanych zmian w gospodarce europejskiej, będzie sporym wyzwaniem. W państwach członkowskich udział subsydiów z WRF i NGEU do zagospodarowania w najbliższych siedmiu latach - bez uwzględnienia niewykorzystanych dotąd środków z WRF 2014-202044 - sięga od kilku do kilkunastu procent PKB (np. 2,3\% we Francji, 6,4\% we Włoszech, 8,2\% w Hiszpanii i 17,8\% w Polsce) ${ }^{45}$. Ponadto, jak podkreśla się w Europejskim Trybunale Obrachunkowym, ważne jest, aby wydatkowanie funduszy odbywało się sprawnie i zgodnie z założonymi celami, a ryzyko wystąpienia nieprawidłowości i nadużyć w wydawaniu tak dużych dodatkowych kwot było stale minimalizowane ${ }^{46}$.

44 Według danych Komisji Europejskiej w czerwcu 2021 r. średnia absorpcja alokacji dla polityki spójności w WRF 2014-2020 sięgała 50\% (środki wydane). Por.: https://cohesiondata.ec.europa.eu [dostęp: 10 września 2021 r.].

45 A. Eisl, E. Rubio, Spending EU Subsidies Well: a Challenge for Member States, Jacques Delors Institute, 2021; Z. Darvas, Will European Union Countries Be Able to Absorb and Spend Well the Bloc's Recovery Funding?, Bruegel, 2020.

46 Opinia 6/2020 w sprawie wniosku dotyczącego rozporządzenia Parlamentu Europejskiego i Rady ustanawiającego Instrument na rzecz Odbudowy i Zwiększania Odporności (COM(2020) 408 final) (Dz.Urz. UE ( 350 z dnia 20 października 2020 r.). 
Zgodnie z art. 21 rozporządzenia o WRF 2021-2027 Komisja Europejska ma przedstawić propozycję kolejnych wieloletnich ram finansowych przed 1 lipca 2025 r. Tymczasem dyskusja nad kierunkami zmian w sferze finansowania UE trwa i można oczekiwać, że będzie nabierać tempa. Rozpoczęta niedawno Konferencja w sprawie Przyszłości Europy powinna być okazją do przedstawienia konkretnych pomysłów. Wśród zagadnień wymagających nie tylko refleksji, lecz także konkretnych działań wymienia się zwłaszcza dalsze zmiany w systemie zasobów własnych budżetu UE oraz reformę mechanizmu podejmowania decyzji o $\mathrm{WRF}^{47}$.

\section{Bibliografia}

Ackrill R., Kay A., Historical-Institutionalist Perspectives on the Development of the EU Budget System, "Journal of European Public Policy" 2006, t. 13, nr 1, https://doi.org/10.1080/13501760500380775.

Barcz J., Od lizbońskiej do postlizbońskiej Unii Europejskiej. Główne kierunki reformy ustrojowej procesu integracji europejskiej, Wolters Kluwer, Warszawa 2020.

Bauer M.W., Becker S., Assessing the European Parliament's Power of the Purse: Rights, Capabilities, and Strategies [w:] The New Politics of the European Union Budget, red. S. Becker, M.W. Bauer, A. De Feo, Nomos, Baden-Baden 2017.

Clemens F., Pisani-Ferry J., A Primer on Developing European Public Goods, „EconPol Policy Report” 2019, nr 16.

Crowe R., An EU Budget of States and Citizens, „European Law Journal” 2021, https://doi.org/10.1111/eulj.12398.

Darvas Z., Will European Union Countries Be Able to Absorb and Spend Well the Bloc's Recovery Funding?, Bruegel, 2020.

D'Alfonso A., Matching Priorities and Resources in the EU Budget. Climate Action, Migration and Borders, European Parliament, 2021.

D'Alfonso A., Own Resources of the European Union. Reforming the EU's Financing System, European Parliament, 2021.

De Feo A., The Multiannual Financial Framework 2021-2027: Ambition or Continuity? [w:] EU Financing for Next Decade. Beyond the MFF 2021-2027 and the Next Generation EU, red. B. Laffan, A. De Feo, European University Institute, Florence 2020.

Drachenberg R., The Role of the European Council in Negotiating the 2021-2027 MFF, European Parliament, 2021. Eisl A., Rubio E., Spending EU Subsidies Well: A Challenge for Member States, Jacques Delors Institute, 2021.

Haas J., Rubio E., Schneemelcher P., The MFF Proposal: What's New, What's Old, What's Next?, Jacques Delors Institute, 2018.

Kaiser R., Prange-Gstöhl H., The European Union Budget in Times of Crises, Nomos, Baden-Baden 2021, https:// doi.org/10.5771/9783845298115-1.

Kowald K., Natural Resources and Environment. Heading 3 of the 2021-2027 MFF, European Parliament, 2021.

Leyen U. von der, A Union that Strives for More. My Agenda for Europe. Political Guidelines for the Next European Commission 2019-2024, Brussels 2019.

47 R. Crowe, An EU Budget of States and Citizens, „European Law Journal” 2021, s. 1-14, https://doi.org/10.1111/ eulj.12398; N. von Ondarza, M. Álander, The Conference on the Future of Europe. Obstacles and Opportunities to European Reform Initiative That Goes Beyond Crisis Management, Stiftung Wissenschaft und Politik, Berlin 2021, https://doi.org/10.18449/2021C19. 
Neheider S., Santos I., Reframing the EU Budget-Decision-Making Process, „Journal of Common Market Studies" 2011, t. 49, nr 3, https://doi.org/10.1111/j.1468-5965.2010.02148.x.

Ondarza N. von, Álander M., The Conference on the Future of Europe. Obstacles and Opportunities to European Reform Initiative That Goes Beyond Crisis Management, Stiftung Wissenschaft und Politik, Berlin 2021, https:// doi.org/10.18449/2021C19.

Parry M., Sapała M., 2021-2027 Multiannual Financial Framework and New Own resources. Analysis of the Commission's Proposal, European Parliament, 2018.

Recovery fund is a huge breakthrough for the EU, "The Financial Times”, 21 lipca $2020 \mathrm{r}$.

Rubio E., Negotiating the Next Multiannual Financial Framework in an Electoral Year: Which Consequences?, Jacques Delors Institute, 29 listopada $2018 \mathrm{r}$.

Sapała M., Cohesion, Resilience and Values. Heading 2 of the 2021-2027 MFF, European Parliament, 2021.

Sapała M., Pari M., Kresnichka-Nikolchova N., EU Financing for 2021-2027, European Parliament, 2020.

Sapała M., Thomassen N., Recovery Plan for Europe: State of Play, European Parliament, 2021.

Vitrey A., How and why did the European Parliament Influence the Reform of the Own Resources System? [w:] EU Financing for Next Decade. Beyond the MFF 2021-2027 and the Next Generation EU, red. B. Laffan, A. De Feo, European University Institute, Florence 2020.

Zuleeg F., Pilati M., The MFF: Europe's Other Ticking Clock, European Policy Centre, 2019.

\section{Akty prawne i dokumenty}

Decyzja Rady (UE, Euratom) 2020/2053 z dnia 14 grudnia 2020 r. w sprawie systemu zasobów własnych Unii Europejskiej oraz uchylająca decyzję 2014/335/UE (Dz.Urz. UE L 424 z dnia 15 grudnia 2020 r.).

Deklaracja rzymska, Rada Europejska, 25 marca 2017 r.

Deklaracja z Bratysławy, Rada Europejska, 16 września 2016 r.

Dokument otwierający debatę na temat przyszłości finansów UE (COM(2017) 358 final) z dnia 28 czerwca 2017 r.

Komunikat Komisji do Parlamentu Europejskiego i Rady. Śródokresowy przegląd/rewizja wieloletnich ram finansowych na lata 2014-2020. Budżet UE ukierunkowany na wyniki (COM(2016) 603 final).

Opinia nr 6/2020 w sprawie wniosku dotyczącego rozporządzenia Parlamentu Europejskiego i Rady ustanawiającego Instrument na rzecz Odbudowy i Zwiększania Odporności (COM(2020) 408 final) (Dz.Urz. UE C 350 z dnia 20 października 2020 r.).

Porozumienie międzyinstytucjonalne z dnia 16 grudnia 2020 r. między Parlamentem Europejskim, Radą Unii Europejskiej i Komisją Europejską w sprawie dyscypliny budżetowej, współpracy w kwestiach budżetowych i należytego zarządzania finansami oraz w sprawie nowych zasobów własnych, w tym również harmonogramu wprowadzania nowych zasobów własnych (Dz.Urz. UE L 433 I z dnia 22 grudnia 2020 r.).

Rezolucja Parlamentu Europejskiego w sprawie konkluzji z nadzwyczajnego posiedzenia Rady Europejskiej w dniach 17-21 lipca 2020 r. (2020/2732(RSP)).

Rezolucja Parlamentu Europejskiego z dnia 15 kwietnia 2014 r. w sprawie negocjacji dotyczących WRF na lata 2014-2020: wnioski i dalsze działania (2014/2005(INI)) (Dz.Urz. UE C 443 z dnia 22 grudnia 2017 r.).

Rezolucja Parlamentu Europejskiego z dnia 24 października 2017 r. w sprawie dokumentu otwierającego debatę na temat przyszłości finansów UE (2017/2742(RSP)) (Dz.Urz. UE C 346 z dnia 27 września 2018 r.). 
Rezolucja Parlamentu Europejskiego z dnia 14 marca 2018 r. w sprawie następnych WRF: przygotowanie stanowiska Parlamentu dotyczącego WRF na okres po 2020 r. (2017/2052(INI)) (Dz.Urz. UE C 162 z dnia 10 maja 2019 r.).

Rezolucja Parlamentu Europejskiego z dnia 14 marca 2018 r. w sprawie reformy systemu zasobów własnych Unii Europejskiej (2017/2053(INI)) (Dz.Urz. UE C 162 z dnia 10 maja 2019 r.).

Rezolucja Parlamentu Europejskiego z dnia 30 maja 2018 r. w sprawie wieloletnich ram finansowych na lata 2021-2027 i zasobów własnych: czas, by spełnić oczekiwania obywateli (2019/2833(RSP)).

Rezolucja Parlamentu Europejskiego z dnia 13 maja 2020 r. zawierająca zalecenia dla Komisji w sprawie siatki bezpieczeństwa chroniącej beneficjentów programów UE: ustanowienie planu awaryjnego dotyczącego WRF (2020/2051(INL)) (Dz.Urz. UE C 323 z dnia 11 sierpnia 2021 r.).

Rozporządzenie Parlamentu Europejskiego i Rady (UE, Euratom) 2020/2092 z dnia 16 grudnia 2020 r. w sprawie ogólnego systemu warunkowości służącego ochronie budżetu Unii (Dz.Urz. UE L 433 I z dnia 22 grudnia 2020 r.).

Rozporządzenie Parlamentu Europejskiego i Rady (UE) 2021/241 z dnia 12 lutego 2021 r. ustanawiające Instrument na rzecz Odbudowy i Zwiększenia Odporności (Dz.Urz. UE L 57 z dnia 18 lutego 2021 r.).

Rozporządzenie Rady (UE, Euratom) nr 1311/2013 określające wieloletnie ramy finansowe na lata 2014-2020 (Dz.Urz. UE L 347 z dnia 20 grudnia 2013 r.).

Rozporządzenie Rady (UE, Euratom) 2020/2093 z dnia 17 grudnia 2020 r. określające wieloletnie ramy finansowe na lata 2021-2027 (Dz.Urz. UE L 433 z dnia 22 grudnia 2020 r.).

Rozporządzenie Rady (UE, Euratom) 2021/768 z dnia 30 kwietnia 2021 r. określające środki wykonawcze dotyczące systemu zasobów własnych Unii Europejskiej oraz uchylające rozporządzenie (UE, Euratom) nr 608/2014 (Dz.Urz. UE L 165 z 11 maja 2021 r.).

Rozporządzenie Rady (UE, Euratom) 2021/769 z dnia 30 kwietnia 2021 r. zmieniające rozporządzenie Rady (EWG, Euratom) nr 1553/89 w sprawie ostatecznych jednolitych warunków poboru środków własnych pochodzących z podatku od wartości dodanej (Dz.Urz. UE L 165 z 11 maja 2021 r.).

Rozporządzenie Rady (UE) 2020/2094 z dnia 14 grudnia 2020 r. ustanawiające Instrument Unii Europejskiej na rzecz Odbudowy w celu wsparcia odbudowy w następstwie kryzysu związanego z COVID-19 (Dz.Urz. UE L 433 z dnia 22 grudnia 2020 r.).

Sprawozdanie okresowe w sprawie wieloletnich ram finansowych na lata 2021-2027 - stanowisko Parlamentu z myślą o osiągnięciu porozumienia, 14 listopada 2018 r. (2018/0166R(APP)).

Sprawozdanie w sprawie negocjacji dotyczących WRF na lata 2014-2020: wnioski i dalsze działania (2014/2005(INI)).

Zalecenie w sprawie projektu rozporządzenia Rady określającego wieloletnie ramy finansowe na lata 20212027 (2018/0116(APP)).

\section{Strony internetowe}

European Commission, Cohesion data, https://cohesiondata.ec.europa.eu.

European Commission, Future Financing of the EU. Final Report and Recommendations of the High Level Group on Own Resources, 2016, https://ec.europa.eu/info/sites/default/files/about_the_european_commission/ eu_budget/future-financing-hlgor-final-report_2016_en.pdf. 
European Commission, Integrated Financial and Accountability Reporting IFAR. Financial Year 2020, 2021, https:// ec.europa.eu/info/sites/default/files/about_the_european_commission/eu_budget/overview_ifar_web1. pdf.

European Commission, Legal Texts and Factsheets on the EU Budget for the Future, 2018, https://ec.europa.eu/ info/publications/factsheets-long-term-budget-proposals_en.

European Commission, MFF Legis/ation, https://ec.europa.eu/info/publications/mff-legislation_en.

European Court of Auditors, Future of EU Finances: Reforming How the EU Budget Operates. Briefing Paper, Luxembourg 2018, https://www.eca.europa.eu/other\%20publications/briefing_paper_mff/briefing_paper_ mff_en.pdf.

European Parliamentary Research Service, Visualising the European Union 2021-2027 MFF and recovery instrument, https://www.europarl.europa.eu/thinktank/infographics/mff2021-2027/index.html.

The EU's Recovery Fund is a Benefit of Brexit, "The Economist", 30 maja 2020 r., https://www.economist.com/ europe/2020/05/30/the-eus-recovery-fund-is-a-benefit-of-brexit.

France Says EU Recovery Fund Cannot Come at Expense of Long-Term Budget, Reuters, 26 maja 2020 r., https:// www.reuters.com/article/us-eu-recovery-france-idINKBN2321NP.

Legislative Observatory, https://oeil.secure.europarl.europa.eu/oeil/home/home.do.

Rada Europejska, Wystqpienie Donalda Tuska po nieformalnym spotkaniu 27 szefów państw i rządów (23 lutego 2018 r.), 2018, https://www.consilium.europa.eu/pl/press/press-releases/2018/02/23/remarks-by-president-donald-tusk-following-the-informal-meeting-of-the-27-heads-of-state-or-government-on-23-february-2018/pdf.

Why the EU is becoming more like a Chekhov play, "The Economist", 25 lipca 2020 r., https://www.economist.com/ europe/2020/07/23/why-the-eu-is-becoming-more-like-a-chekhov-play. 